\title{
A BILAYERED TISSUE ENGINEERED IN VITRO MODEL SIMULATING THE TOOTH PERIODONTIUM
}

\author{
A. Khadre ${ }^{1,3}$, E.L.M. Raif ${ }^{1}$, S. Junaid ${ }^{4}$, O.M. Goudouri' ${ }^{2}$, W. Refaat ${ }^{3}$, A. Ramadan ${ }^{3}$, A.R. Boccaccini ${ }^{2}$ \\ and R. El-Gendy , $^{1, *}$ \\ ${ }^{1}$ Department of Oral Biology, Leeds School of Dentistry, University of Leeds, UK \\ ${ }^{2}$ Department of Materials Science and Engineering, Institute of Biomaterials, \\ University Erlangen-Nuremberg, Germany \\ ${ }^{3}$ Department of Orthodontics, Faculty of Dentistry, Suez Canal University, Ismailia, Egypt \\ ${ }^{4}$ Department of Mechanical Engineering and Design, School of Engineering and Applied Science, \\ Aston University, Birmingham, UK \\ ${ }^{5}$ Department of Oral Pathology, Faculty of Dentistry, Suez Canal University, Ismailia, Egypt
}

\begin{abstract}
Due to the complexity of the structure of the tooth periodontium, regeneration of the full tooth attachment is not a trivial task. There is also a gap in models that can represent human tooth attachment in vitro and in vivo. The aim of this study was to develop a bilayered in vitro construct that simulated the tooth periodontal ligament and attached alveolar bone, for the purpose of tissue regeneration and investigation of physiological and orthodontic loading. Two types of materials were used to develop this construct: sol-gel 60S10Mg derived scaffold, representing the hard tissue component of the periodontium, and commercially available Geistlich Bio-Gide ${ }^{\circledast}$ collagen membrane, representing the soft tissue component of the tooth attachment. Each scaffold was dynamically seeded with human periodontal ligament cells (HPDLCs). Scaffolds were either cultured separately, or combined in a bilayered construct, for 2 weeks. Characterisation of the individual scaffolds and the bilayered constructs included biological characterisation (cell viability, scanning electron microscopy to confirm cell attachment, gene expression of periodontium regeneration markers), and mechanical characterisation of scaffolds and constructs. HPDLCs enjoyed a biocompatible 3-dimensional environment within the bilayered construct components. There was no drop in cellular gene expression in the bilayered construct, compared to the separate scaffolds.
\end{abstract}

Keywords: Periodontal regeneration, physiologic simulation, in vitro models, bilayered construct, tissue engineering, periodontal ligament cells.

*Address for correspondence: Dr Reem El-Gendy, Department of Oral Biology, School of Dentistry, Faculty of Medicine \& Health, Level 7, Welcome Trust Brenner Building, University of Leeds, St James's University Hospital, Leeds, LS9 7TF, UK.

Telephone number: +4401133438062 Email: R.El-Gendy@leeds.ac.uk

Copyright policy: This article is distributed in accordance with Creative Commons Attribution Licence (http://creativecommons.org/licenses/by-sa/4.0/).

\section{List of Abbreviations}

$2 \mathrm{D}$

$3 \mathrm{D}$

$\mathrm{AM}$

BGC

$\mathrm{CD}$

CEMP1

COL1A1

EDTA

EthD-1

FBS

FGF 2-dimensional

3-dimensional

acetoxymethyl

Bio-Gide ${ }^{\circledR}$ construct component

cluster of differentiation

cementum

collagen type I alpha 1 chain

ethylenediaminetetraacetic acid

ethidium homodimer-1

foetal bovine serum

fibroblast growth factor
GAPDH glyceraldehyde 3-phosphate dehydrogenase

GTR guided tissue regeneration

HPDLCs human periodontal ligament cells

$\mathrm{LDH} \quad$ lactate dehydrogenase

OC osteocalcin

OPG osteoprotegerin

PDL periodontal ligament

PECAM1 platelet and endothelial cell adhesion molecule 1

qRT-PCR quantitative real time PCR

RANKL RANK ligand

RLT buffer buffer for lysis of cells and tissues 
RPE

RW1

SD

SEM

SGC

VEGF

$\alpha$-MEM proprietary RNA wash buffer proprietary RNA wash buffer standard deviation

scanning electron microscope sol-gel construct component vascular endothelial growth factor $\alpha$-modified minimum essential medium

\section{Introduction}

Due to the complexity of the tooth periodontium (Jang et al., 2014), and root cementum, regeneration of the full tooth attachment is not a trivial task, especially when attempting to restore function and simulate physiological dynamics (Sumita et al., 2006; Young et al., 2002). The ideal periodontal therapy involves regeneration of the different tissues that comprise the tooth attachment apparatus (Bai et al., 2021), as well as restoration of the physiological function of the periodontium including shock absorbing function under mechanical loading (Cho and Garant, 2000). Current regenerative periodontal therapies include GTR (Araujo et al., 1998), which uses a membrane that allows the growth and regeneration of the hard and soft tissues of the periodontium as well as allowing restoration of physiological architecture of the tooth attachment (Yamada and Cukierman, 2007). However, current regenerative therapies, although successful in many cases, still have unpredictable outcomes in many others. Furthermore, current GTR treatment is known to be more successful in specific lesions and sites (infra-bony defects, molar class-II bifurcation) compared to others (Camargo et al., 2005).

There is also a gap in models that represent the human tooth attachment, allow investigating regeneration therapies and the effects of orthodontic tooth movements on the periodontium, in vitro and in vivo (Yang et al., 2015). In vivo animal models, despite being ethically controversial, can give an idea about the success of periodontal treatment but still lack the exact resemblance to human physiology. The results of animal model experiments are often not transferrable to humans, and this is only discovered when clinical trials provide very different results from the animal models (Yijin et al., 2006). Hence it was important to use the emerging tissue engineering techniques to develop models and constructs that represent the complexity and diversity of the periodontium for regeneration and in vitro modelling purposes, such as studying the effect of orthodontic and physiological mechanical forces on the periodontium. However, many of the available models have limitations in representing tissue diversity or physiological conditions (Kanzaki et al., 2004; Oortgiesen et al., 2012).

In vitro and in situ models that use human cells cultured in monolayers or periodontal multilayered cell sheets lack mechanobiology and simulation of mechanical loading (Iwata et al., 2009; Raju et al., 2020;
Yang et al., 2015). In a recent study, the development of a whole porcine tooth in situ model was attempted. However, the inability to maintain long-term sample viability and sterility in culture for more than $8 \mathrm{~d}$, posed a great disadvantage. Furthermore, in spite of this model being the closest to physiological condition, control over tissues and cells as well as testing individual cell responses have proven to be extremely challenging in this model (El-Gendy et al., 2020).

Self-assembling peptide P11-4, a smart scaffold, was successfully used to regenerate critical PDL defects in a rat model (El-Sayed et al., 2020). The same scaffold was used by Koch et al., 2020 to develop a 3D PDL model. The model tested cell migration and coverage of dentine surface but did not represent the architecture or the tissue hierarchy of the periodontium (Koch et al., 2020). 3D printing technologies enabled Lee et al., 2013, to create a successful multiphasic periodontal model. However, the complexity involved in developing the model, which included printing of 3 different hydroxyapatite phases and seeding 3 cell types on different types of hydrogels, through the printed channels, and a cocktail of growth factors make its cost effectiveness, practicality and versatility questionable (Lee et al., 2013). To create such a complex model, the right choice of stem/progenitor cells as well as materials is required (Ivanovski et al., 2006; Yu et al., 2014). The stem cells must have the capacity to differentiate into the different tissues that comprise the periodontium (Gay et al., 2007). A compartmental multi/biphasic approach must be used to regenerate the periodontium. This approach will require the use of different biomaterials to represent hard tissue and soft tissue components of the periodontium (Chen et al., 2008). The diversity of the surface topography of the materials will play a role in directing the differentiation route of the cells (Elisseeff et al., 2005; Jäger et al., 2006). Furthermore, mechanical characterisation of multiphasic constructs is essential in future applications of such models (Sabree et al., 2015). However, practicality, cost effectiveness, and versatility of the model are also key characters for the success of the model.

The aim of this study was to develop a biphasic/ bilayered tissue engineered construct with a soft tissue component representing the PDL and a hard tissue component representing the alveolar bone, and to characterise the construct biologically and mechanically. Future applications of such a construct could include periodontium regeneration; skeletal tissue regeneration that requires multiphasic tissue engineering; hard-soft tissue interaction; characterisation of interfaces between tissues, materials, and cells - such as osteochondral, bonetendon, bone-ligament interfaces. Investigation the effect of orthodontic loading on periodontium, and biomechanical characterisation of bone and skeletal tissues are overarching translational goals of this construct. 


\section{Materials and Methods}

Cell culture plastics were purchased from Corning. Phosphate-buffered saline solution, $\alpha$-MEM and FBS were obtained from Lonza. Antibiotics, growth factors, enzymes, and other reagents were purchased from Sigma-Aldrich, unless stated otherwise.

All scaffolds were sterilised using an Ultraviolet light source (UVP Upland, Upland, CA, USA), for $30 \mathrm{~min}$, in the tissue culture hood. Sol-gel derived scaffolds were developed at University of ErlangenNuremberg, Germany. The Bio-Gide ${ }^{\circledR}$ Perio was generously supplied by (Geistlich Pharma AG) in Switzerland.

\section{Scaffold fabrication and preparation}

Sol-gel derived scaffolds (sol-gel scaffolds)

Scaffolds $(9 \times 5 \times 9 \mathrm{~mm})$ were produced by the sol-gel technique combined with the foam replica method in the $\mathrm{SiO}_{2}(60 \%)-\mathrm{CaO}(30 \%)-\mathrm{MgO}(10 \%)$ system (Goudouri et al., 2016, Blehert et al., 2003, Chen et al., 2006). The scaffolds were coated with gelatingenipin as described elsewhere (Goudouri et al., 2016). Genipin is a naturally occurring cross-linking agent used to cross-link the gelatine as it is considered nontoxic (Tsai et al., 2000). Genipin can spontaneously react with amino acids or proteins to form dark blue pigments, which has been used in the fabrication of food dyes and produces the dark blue colour of the scaffolds (Fig. 1a).

\section{Geistlich Bio-Gide ${ }^{\circledR}$ Perio membrane}

Geistlich Bio-Gide ${ }^{\circledR}$ Perio membrane is a commerciallyavailable collagen membrane, made of natural purified porcine collagen without further cross linking or chemical additives. This membrane is used clinically to treat advanced periodontal defects in GTR surgeries (Araujo et al., 1998; Camelo et al., 2001; Ramseier et al., 2006; Sculean et al., 2004). Geistlich's Bio-Gide ${ }^{\circledR}$ membrane is double sided, the porous side allows the penetration and growth of osteoblasts, hence it is placed facing the alveolar bone during GTR, whilst the dense face is placed adjacent to the soft tissue to prevent epithelial growth into the bony defect during GTR (Pietruska, 2001). Each Geistlich Bio-Gide ${ }^{\circledR}$ membrane $(30 \times 40 \mathrm{~mm})$ was cut into 9 circular scaffolds of equal diameters $(9 \mathrm{~mm})$ using a sterilised circular sharp cork borer (Fig. 1b).

\section{Isolation and culture of HPDLCs \\ Cell isolation}

Freshly extracted wisdom teeth were provided through the Leeds School of Dentistry skeletal and dental tissue bank after patients' informed consent. HPDLCs were isolated from middle third of extracted healthy wisdom teeth. The cells were maintained in basal culture medium ( $\alpha$-MEM supplemented with $20 \%$ FBS, $200 \mathrm{mmol} / \mathrm{L}$ of l-glutamine, and 100 units/ $\mathrm{mL}$ penicillin/streptomycin) at $37^{\circ} \mathrm{C}$ and $5 \% \mathrm{CO}_{2}$ until $80 \%$ confluent.

\section{HPDLCs culture in monolayers}

Passage (4) HPDLCs were seeded in 6-well plates at a density of $2.5 \times 10^{5}$ cells per well $(n=3)$. HDPLCs were cultured under basal conditions (the same conditions as the scaffolds) for 2 weeks. Monolayers were used as controls for qRT-PCR and LDH assay experiments. Media were collected for LDH assays for up to $14 \mathrm{~d}$. HPDLCs at zero time point (not previously expanded in culture), were used as negative controls for monolayer HPDLCs and 3D structures that were cultured for 2 weeks.
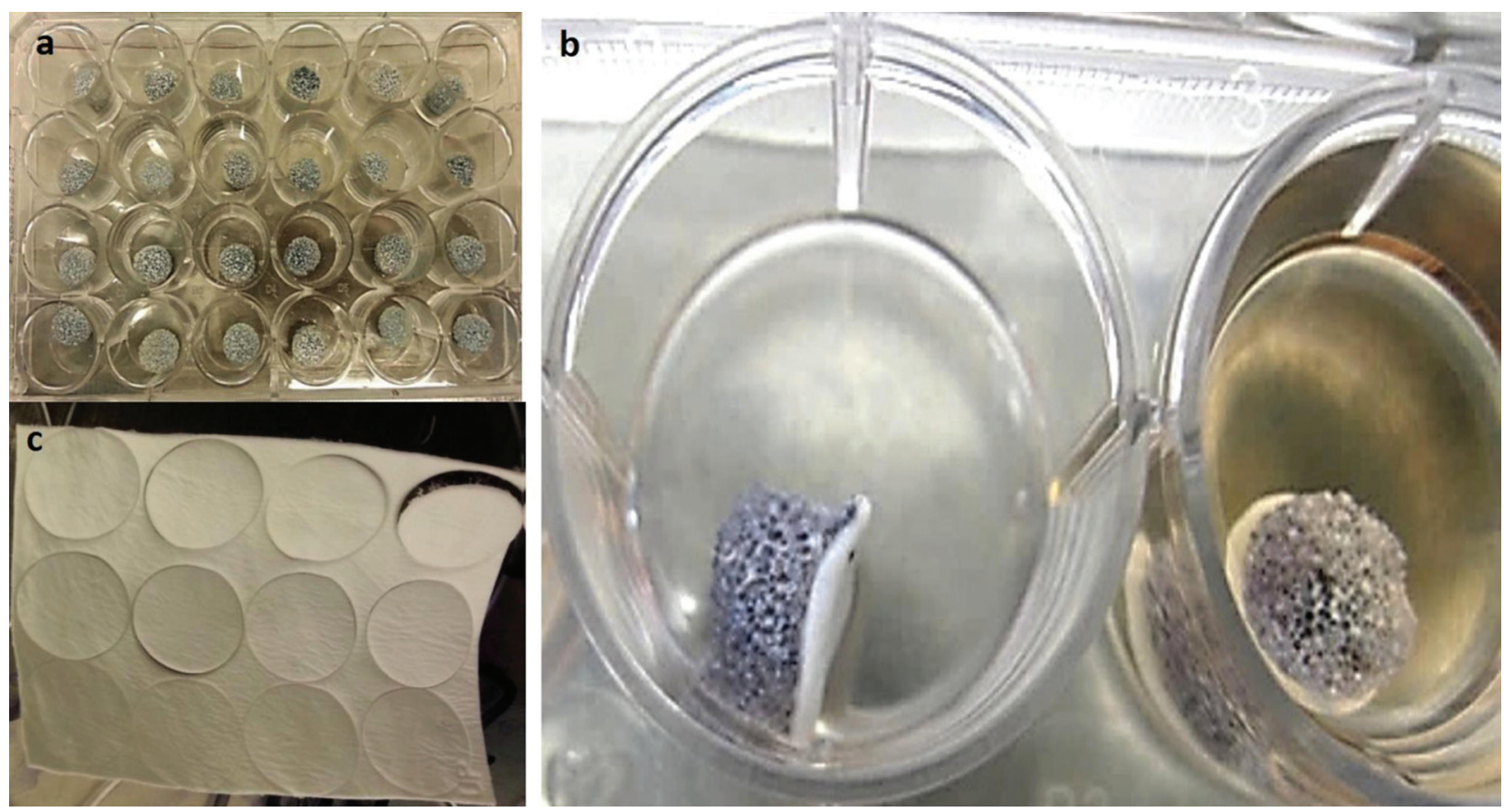

Fig. 1. Images of scaffolds used. (a) Sol-gel. (b) BioGide ${ }^{\circledR}$. (c) Assembled bilayered construct. 


\section{Cell seeding and bilayered construct assembly} Individual scaffold seeding

$2.5 \times 10^{5}$ cells were dynamically seeded on each scaffold type, $n=3$ /group, for both sol-gel scaffolds and Bio-Gide ${ }^{\circledR}$ membrane separately. Dynamic seeding was performed using Macs Mix ${ }^{\circledR}$ (Miltenyi Biotech, Cologne, Germany) tube rotator machine. After $48 \mathrm{~h}$ of rotation the scaffolds were transferred to 12-well plates and were then cultured for 2 weeks, the media were changed twice a week.

\section{Bilayered construct assembly}

After $48 \mathrm{~h}$ of dynamic seeding, the sol-gel scaffolds were placed on top of the Bio-Gide ${ }^{\circledR}$ membrane in a 12-well plate so that the porous surface of the BioGide $^{\circledR}$ membrane was in contact with the scaffold giving a bilayered construct (Fig. 1c). The constructs were then cultured in this arrangement for 2 weeks and media were changed twice weekly.

\section{SEM imaging}

Unseeded, individually seeded scaffolds (sol-gel scaffolds and Bio-Gide ${ }^{\circledR}$ membrane) and seeded bilayered constructs were examined and imaged using an SEM (JEOL JSM 5610LV). Bio-Gide ${ }^{\circledR}$ membranes were imaged on both porous and dense sides. Seeded scaffolds were also imaged using the SEM to determine the cell attachment, proliferation, and formation of extracellular matrix. Furthermore, bilayered constructs were examined at the interface between the two scaffolds and each scaffold was imaged after being detached from the bilayered SGC-and-BGC construct. Imaging of seeded scaffolds and constructs was carried out after 2 weeks of culture. All samples were fixed in $4 \%$ neutral buffered formaldehyde, dehydrated using ascending concentrations of alcohol (from $20 \%$ to $100 \%$ ) followed by vaccium dehydration and sputtered with 5-10 nm Au before being imaged by SEM.

\section{Cell viability assays}

Liveldead staining

After 2 weeks of culture, the seeded sol-gel scaffolds, Bio-Gide ${ }^{\circledR}$ membranes and the bilayered constructs were fixed in $4 \%$ neutral buffered formalin, after being stained with viability/cytotoxicity kit (Invitrogen Life Technologies, Waltham, MA, USA) for mammalian cells, according to manufacturer's instructions. Briefly, $10 \mu \mathrm{L}$ EthD-1 and $5 \mu \mathrm{L}$ calcein AM were added to $5 \mathrm{~mL}$ of plain medium. The staining solution was used to stain constructs as follows, $200 \mu \mathrm{L}$ of the staining solution was added to each scaffold/construct and they were then incubated in in the dark at $37^{\circ} \mathrm{C}$ and $5 \% \mathrm{CO}_{2}$, for $30 \mathrm{~min}$. After staining, the scaffold components (SGC and BGC) were detached from the bilayered constructs. Whereas individual scaffold controls were left as they were and imaged using an inverted fluorescent microscope (Leica DMI 6000B, Japan). The Bio-Gide ${ }^{\circledR}$ membranes were imaged on both the dense and porous sides.

\section{LDH assay of cell death}

LDH is a cytosolic enzyme present in many different cell types. When the plasma membrane is damaged, $\mathrm{LDH}$ is released into the cell culture media. LDH that is released on cell lysis is a stable and cytosolic enzyme and converts a tetrazolium salt in the medium to a red formazan product and its increase in culture medium is proportional to the number of dead cells with a compromised cell membrane. An LDH CytoTox $96^{\circledR}$ colorimetric LDH assay kit was used to detect LDH released due to cell death or cell lysis in the monolayer media, individual scaffolds, or the bilayered constructs. Cell death rates were determined by calculating the percentage of cell death under each culture condition compared/normalised to a $100 \%$ cell-kill control.

\section{CytoTox $96^{\circledR}$ reagent preparation}

Assay buffer was thawed in a $37^{\circ} \mathrm{C}$ water bath, then, $12 \mathrm{~mL}$ of the buffer solution was added to the bottle of substrate mix to form the CytoTox $96^{\circledR}$ Reagent. This reagent can be stored for $6-8$ weeks at $-20^{\circ} \mathrm{C}$ in the dark.

Conditioned media were collected from the different sample groups' monolayers, scaffolds, and bilayered constructs and from the positive control (maximum LDH release or $100 \%$ kill), which was prepared by incubating each group in medium containing $1 \%$ Triton $^{\mathrm{TM}} \mathrm{X}-100$ for $2-3 \mathrm{~h}$ prior to medium collection, the experiment also included a blank (plain medium without FBS), negative control (basal medium with FBS) in triplicates. Collected samples were centrifuged for $3 \mathrm{~min}$ at $120 \times g$. Then, triplicates of $50 \mu \mathrm{L}$ of conditioned medium from each sample was transferred to a 96 well plate. $50 \mu \mathrm{L}$ of LDH CytoTox $96^{\circledR}$ reaction mix was added to each well and was incubated for $30 \mathrm{~min}$ at $37^{\circ} \mathrm{C}$. During this period, the plate was covered with a foil, protecting it from light. After $30 \mathrm{~min}$, stop solution $(50 \mu \mathrm{L})$ was added to all wells and then the absorbance was read and recorded by a platereading spectrometer (Varioskan Flash reader) at $490 \mathrm{~nm}$. These data were analysed and presented as absorbance data in comparison to the maximum LDH release.

\section{Mechanical testing}

The unseeded sol-gel scaffold, Bio-Gide ${ }^{\circledR}$ membrane and bilayer construct were tested under compressive mechanical loading using a universal testing machine (Lloyd LR10K, London, UK) with a $20 \mathrm{~N}$ load cell. Constructs and scaffolds seeded with HPDLCs were tested after 2 weeks of culture $(n=3)$. An $8 \mathrm{~mm}$-diameter pin was used to compress the samples in 48-well plates submerged in medium under semi-constrained compression. The crosshead displacement was set to zero at the bottom of the plate before each test. The crosshead was then raised to the height of the samples (height in dry state) and the samples were compressed at a rate of $0.5 \mathrm{~mm} /$ min. Loading continued until complete failure was 
observed or the sample reached a compressive load of $18 \mathrm{~N}$. Mechanical properties were evaluated by calculating the stress, strain, stiffness, and average compressive strength required to induce failure in the sol-gel scaffold, Bio-Gide ${ }^{\circledR}$ membrane and the bilayered construct.

\section{qRT-PCR gene-expression assays}

\section{RNA extraction}

mRNA was extracted using the RNeasy mini kit (Qiagen, UK), according to manufacturer's instructions. Briefly, RLT buffer $+10 \% \beta$-mercaptoethanol were added directly to HPDLCs monolayers. Individual scaffolds (sol-gel and Bio-Gide ${ }^{\circledR}$ ) and scaffolds separated from the construct (SGC and BGC), were minced before adding the RLT buffer. The cell lysates were then mixed with $70 \%$ ethanol, homogenised using a QI shredder (Qiagen, UK) and centrifuged for $15 \mathrm{~s}$ at $120 \times g$. After this step, mRNA was then extracted from monolayers and scaffolds, as described by the kit manufacturer. Briefly, the mRNA was caught in the silicate membrane within the extraction columns, then they were subjected to a series of washes using RW1 and RPE buffers and finally the mRNA was collected in 30-50 $\mu \mathrm{L}$ of RNAse/DNAse-free water. mRNA was quantified using a nano drop (Nanodrop2000, Thermoscientific).

\section{DNAse purification}

After quantification, mRNA from each sample was purified from any remnants of genomic DNA using a DNase I kit (Invitrogen, UK) according to manufacturer's instructions. Briefly, a $20 \mu \mathrm{L}$ reaction volume - using $9 \mu \mathrm{L}$ of sample (up to $1 \mu \mathrm{g}$ of mRNA) added to $1 \mu \mathrm{L}$ of DNAse enzyme and $10 \mu \mathrm{L}$ of buffer - was incubated at room temperature for $15 \mathrm{~min}$, followed by adding $1 \mu \mathrm{L}$ of EDTA and incubating at $65^{\circ} \mathrm{C}$ in a thermal cycler for $10 \mathrm{~min}$.

\section{Reverse transcription (cDNA synthesis)}

$1 \mu \mathrm{g}$ of mRNA from each sample was used for reverse transcription using an ABI High-Capacity RNA-tocDNA kit (ABI, UK), in a $20 \mu \mathrm{L}$ reaction volume according to the supplier's instructions. Briefly, $1 \mu \mathrm{L}$ of enzyme and $10 \mu \mathrm{L}$ of buffer were added to $9 \mu \mathrm{L}$ of purified mRNA sample. The mixture was then incubated at $37^{\circ} \mathrm{C}$ for $1 \mathrm{~h}$, followed by $5 \mathrm{~min}$ at $95^{\circ} \mathrm{C}$ in a thermal cycler.

\section{qRT-PCR gene expression}

The relative changes in osteogenic (COL1A1, and OC), angiogenic (CD31/PECAM1, and VEGFR2), and cementum (CEMP1) marker genes' expression were compared in HPDLCs cultured under the previously designated conditions after 2 weeks of culture. Furthermore, relative expression of $R A N K L /$ $O P G$ expression were also investigated under the previously mentioned conditions. Relative change in gene expression for all markers was analysed using the $\Delta \mathrm{Ct}$ method according to the following formula:

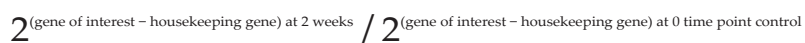

Where housekeeping gene used in this study was GAPDH and the control group was the zero-time point HPDLCs, which have not been expanded in culture.

qRT-PCR was carried out using a Roach LC480 light cycler to amplify and detect the following Taqman ${ }^{\circledR}$ probes: GAPDH: Hs99999905-m1, COL1A1:Hs00164004-m1, CEMP1: HS04185363-s1, PECAM1:Hs01065290-m1, VEGFR2: Hs00911700-m1, RANKL: HS00765721-m1, OPG: HS00900360-m1.

\section{Statistical analysis}

LDH and qRT-PCR results were statistically analysed using the Kruskal-Wallis multiple comparison test with $95 \%$ confidence interval. The statistical analysis was carried out using Graph pad prism version 7. All Rt-PCR and LDH experiments were repeated 3 times $(n=3)$ and had 3 biological replicates $(n=3)$, total $n=9$ data were represented in the form of mean \pm SD.

\section{Results}

\section{Verification of HPDLCs viability}

Live/dead assay of HPDLCs cultured on 3D constructs HDPLSCs seeded Bio-Gide ${ }^{\circledR}$ membranes were imaged on both the porous (Fig. 2a) and dense (Fig. 2b) sides after 2 weeks of culture. All attached cells displayed viable fibroblast-like appearance, indicative of cell spreading on both membrane sides with minimal cell death. Seeded sol-gel scaffolds, after 2 weeks of culture, showed a viable layer of HPDLCs growing on all sides of the scaffold as well as penetrating the scaffold pores. These results confirmed biocompatibility of both scaffolds to HPDLCs (Fig. 2e).

The bilayered constructs were tested after 2 weeks of culture. The sol-gel scaffold, detached from the bilayered construct (SGC), showed a confluent viable layer of HPDLCs covering the scaffold (Fig. 2f). The Bio-Gide ${ }^{\circledR}$ membrane, detached from the bilayered construct (BGC), showed viable HPDLCs on both the porous (Fig. 2c) and the dense (Fig. 2d) sides. However, the porous side showed parts of the remnants of the sol-gel scaffolds attached, denoting good attachment between the bilayered components at the interface (Fig. 2c).

Most cells acquired a green stain (denoting viability) with minimal red stain (denoting minimal cell death) and maintained a fibroblast like morphology indicating that the cells were healthy (Fig. 2a-f).

\section{Quantification of \% cell death using $L D H$}

Significant increase in LDH levels $(p<0.001)$ were observed at days 7 and 14 in the sol-gel scaffolds when compared to spontaneous release from monolayers. The Bio-Gide ${ }^{\circledR}$ membrane showed significant 

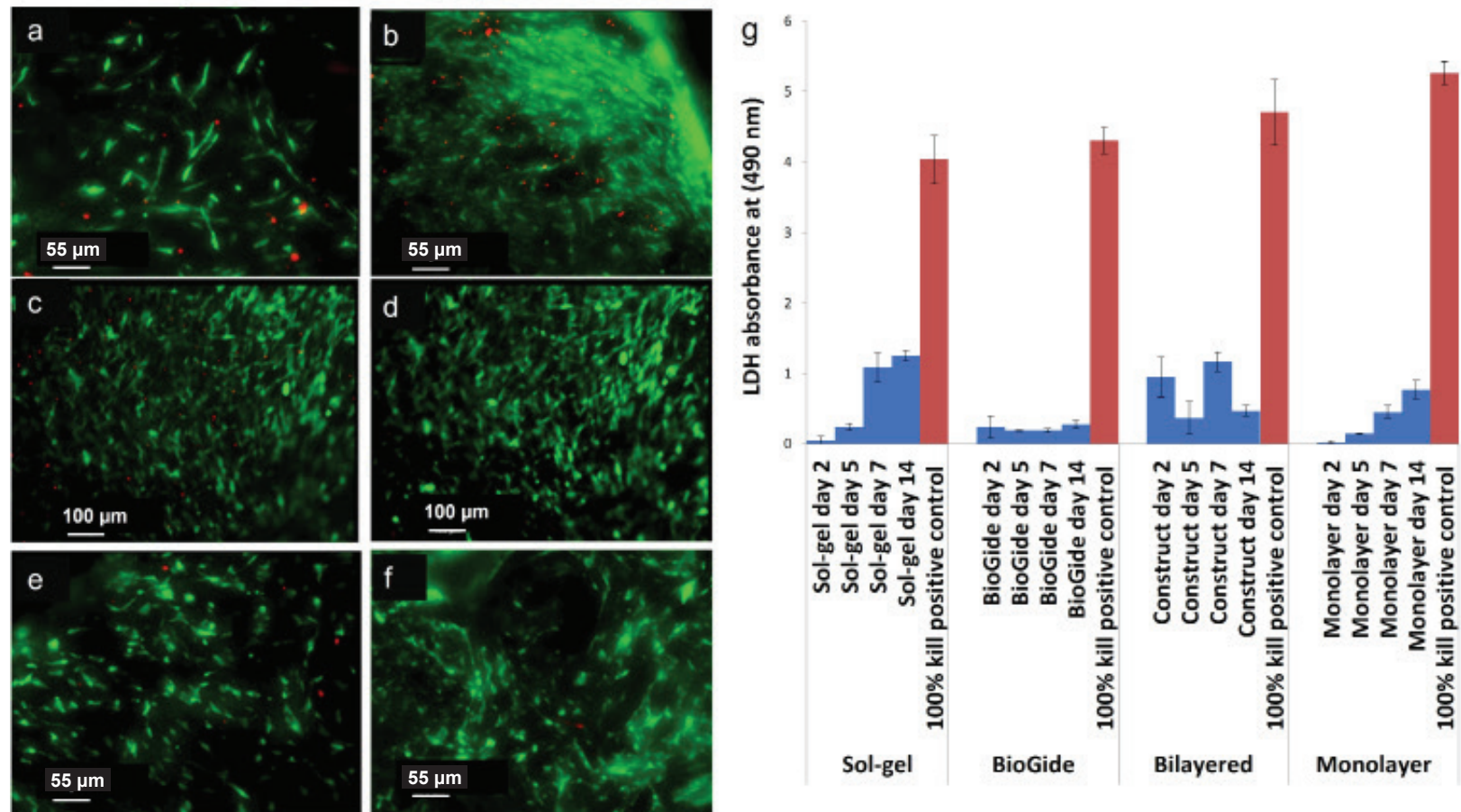

Fig. 2. Viability and growth of HPDLCs after 2 weeks in 3D cultures. (a) BioGide ${ }^{\circledR}$ membrane porous side. (b) BioGide ${ }^{\circledR}$ membrane dense side. (c) BGC porous side (BioGide ${ }^{\circledR}$ membrane detached from construct). (d) BGC dense side (BioGide ${ }^{\circledR}$ membrane detached from construct). (e) sol-gel scaffold. (f) SGC (sol-gel scaffold detached from construct), after 2 weeks in culture. (g) Bar graph showing LDH assay levels in media of seeded 3D cultures; Sol-Gel, BioGide ${ }^{\circledR}$ membrane and bilayered 3D constructs as well as mono-layers HPDLCs at different time points of culture (2, 5, 7 and $14 \mathrm{~d})$. Positive controls are included and represented by the red bars. Values are represented as mean \pm SD.
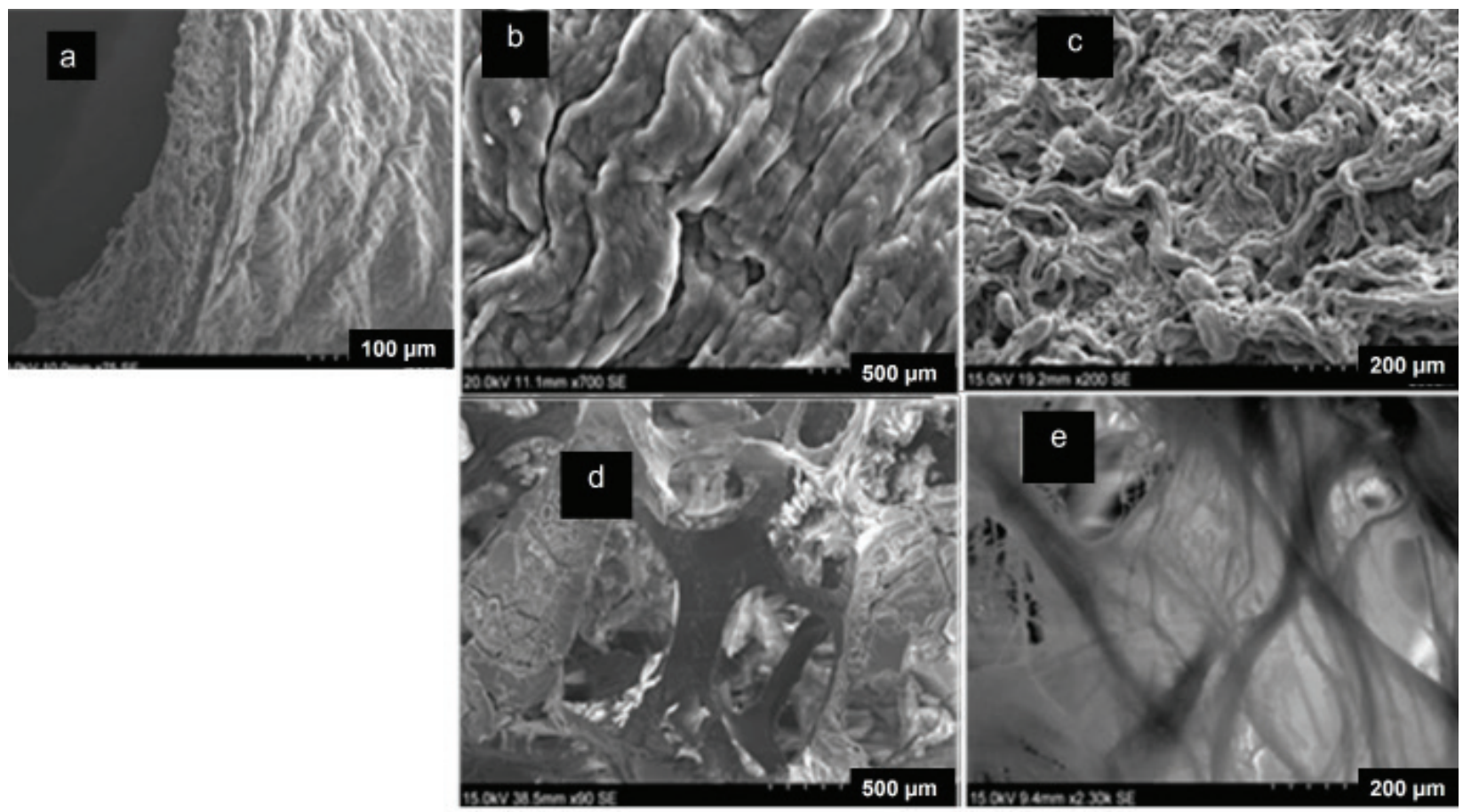

Fig. 3. SEM images of individual scaffolds and bilayered constructs. (a) Unseeded Bio-Gide ${ }^{\circledR}$ membrane showing a cross sectional view of the BioGide membrane. (b) The difference in the structure is evident between unseeded dense side and, (c) the unseeded porous side. (d) The unseeded sol-gel scaffolds showing oval and inter connected pores), and (e) the seeded sol-gel scaffolds after 2 weeks in culture. 
increase in LDH levels $(p<0.05)$ at day 14 only with non-significant increases at days 2, 5 and 7 when compared to monolayer LDH levels. However, when scaffolds were combined in a bilayered construct significant increases in LDH levels $(p<0.001)$ were observed, initially at day 2 but then reduced to nonsignificant levels at days 5, 7, and 14 (Fig. 2g).

\section{SEM imaging of seeded and unseeded scaffolds}

Seeded and unseeded individual scaffolds and constructs were imaged using SEM. The pores in the sol-gel scaffolds had a consistent oval shape (Fig. 3d) with evident interconnectivity. Pore sizes ranged between $686 \pm 68$ and $832 \pm 106 \mu \mathrm{m}$. Unseeded Bio-Gide ${ }^{\circledR}$ membrane structure was confirmed to be porous on one side and dense fibrous on the other side. The collagen fibres were wavy and arranged longitudinally in a parallel manner. The porous side had more interconnectivity with irregular arrangement of fibres compared to the dense side (Fig. 3b,c).

Images of seeded scaffolds (sol-gel scaffolds and Bio-Gide ${ }^{\circledR}$ membrane) after 2 weeks in culture showed HPDLCs spreading and stretching on the surfaces and showed sheets of HPDLCs growing within the scaffolds with typical fibroblast like appearance (Fig. $3 \mathbf{e})$.

Similar images were observed in the bilayered constructs after 2 weeks of culture. Furthermore, when examining the interface of the bilayered constructs, HPDLCs were seen spanning the attachment site after 2 weeks of culture. Seeded scaffolds detached from bilayered construct (SGC and BGC) showed HPDLC extension and growth in sheets within the sol-gel scaffold and on both sides of the Bio-Gide ${ }^{\circledR}$ membrane (Fig. 4e,f).

\section{Mechanical properties of individual scaffolds and} bilayered construct

The compressive load/extension behaviour in the sol-gel scaffold typically showed an initially highstiffness toe region (stage I), a yield region with micro-brittle fractures (stage II) followed by a highstiffness region of material compaction (stage III) (Fig. $5 \mathbf{a}, \mathbf{b})$. The stiffness for stage I and II were calculated as E1 and E2 respectively. On average, after 2 weeks, the unseeded sol-gel scaffold samples $(n=4)$ had a stiffness $( \pm$ SD) of $511 \pm 383 \mathrm{KPa}$ and $219 \pm 113 \mathrm{KPa}$, respectively (Fig. 5a). In comparison, the seeded sol-gel samples with HPDLCs $(n=4)$ showed a considerable decrease in E1 stiffness at $96 \pm 32 \mathrm{KPa}$ and an increase in E2 stiffness at $494 \pm 71 \mathrm{KPa}$ (Fig. 5b).

The Bio-Gide ${ }^{\circledR}$ membrane typically showed a low stiffness toe region followed by a linear increase in stiffness (Fig. 5c,d) The stiffness for the toe and linear stiffness regions were calculated as E1 and E2 respectively. The unseeded membrane $(n=2)$ after 2 weeks showed E1 and E2 stiffness values of $4 \pm 1 \mathrm{KPa}$ and $93 \pm 17 \mathrm{KPa}$ respectively (Fig. 5c). BioGide $^{\circledR}$ samples seeded with HPDLCs $(n=3)$ showed
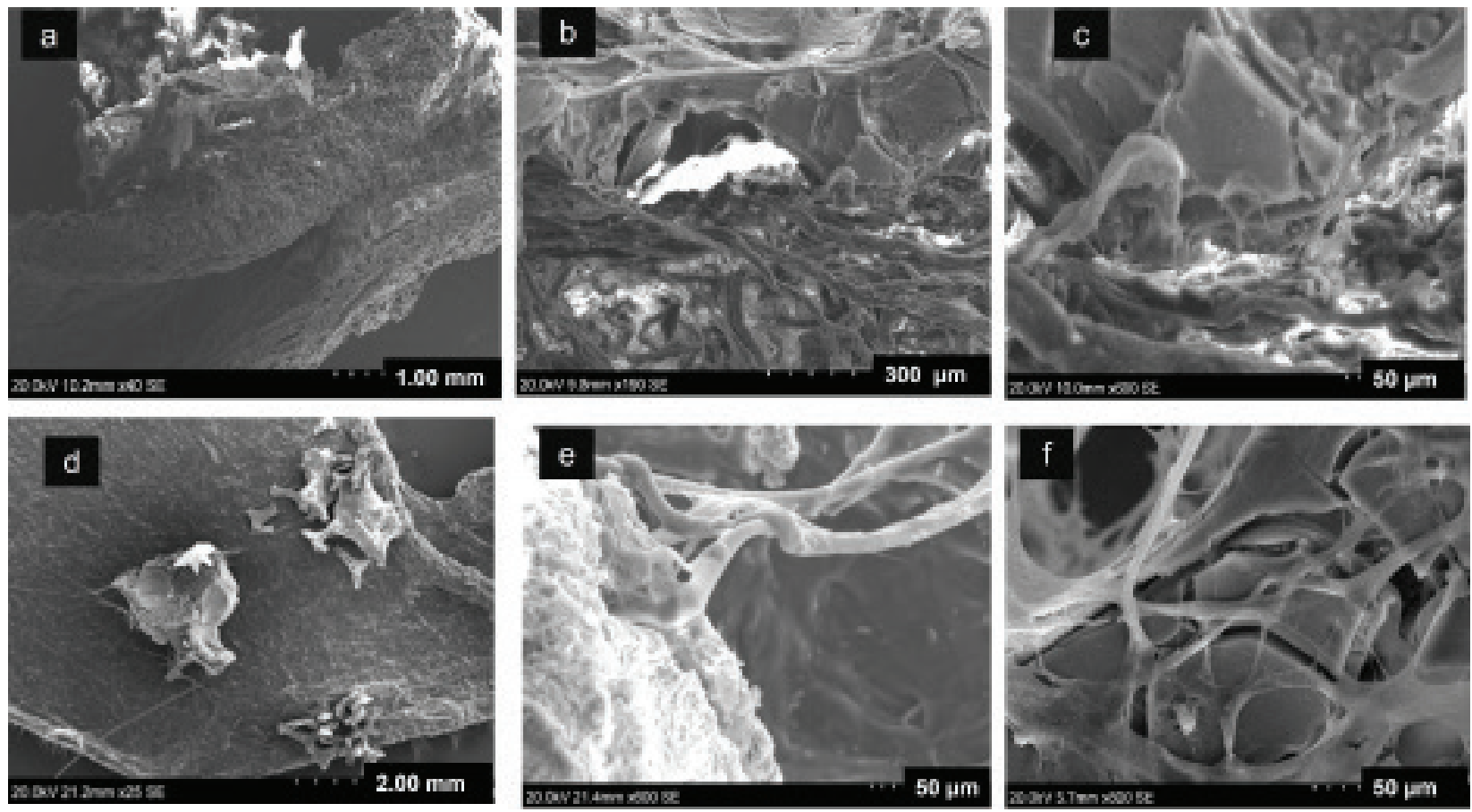

Fig. 4. SEM images at the interface between the two components of the bilayered construct (BioGide ${ }^{\circledR}$ membrane $(\mathbf{a}, \mathbf{b}, \mathbf{d})$ and sol-gel scaffold $(\mathbf{c}, \mathbf{e}, \mathbf{f})$. Images show HPDLCs spreading and stretching within the bilayered construct components, within the scaffold pores and on the surface. Also, sheets of HPDLCs growing within the scaffold - with typical fibroblast-like appearance. Also (d) showing the remnants of SGC on BGC after their detachment. 

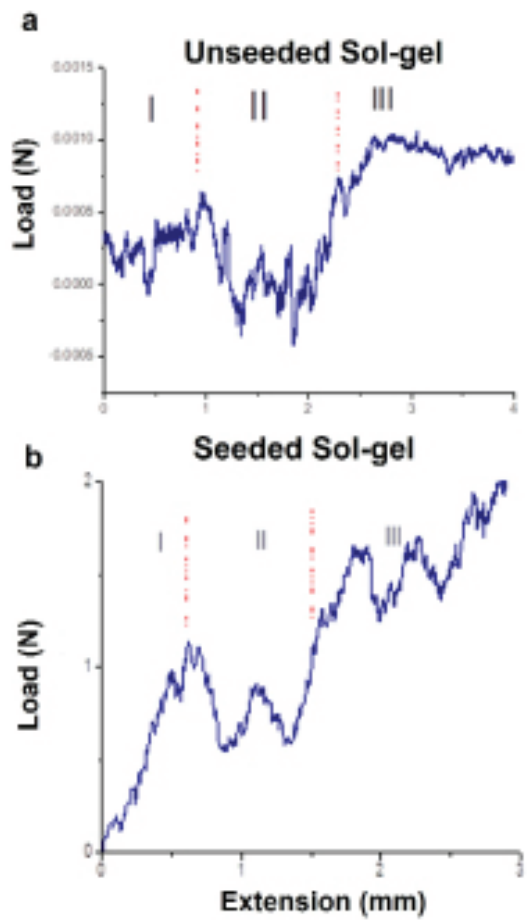

c
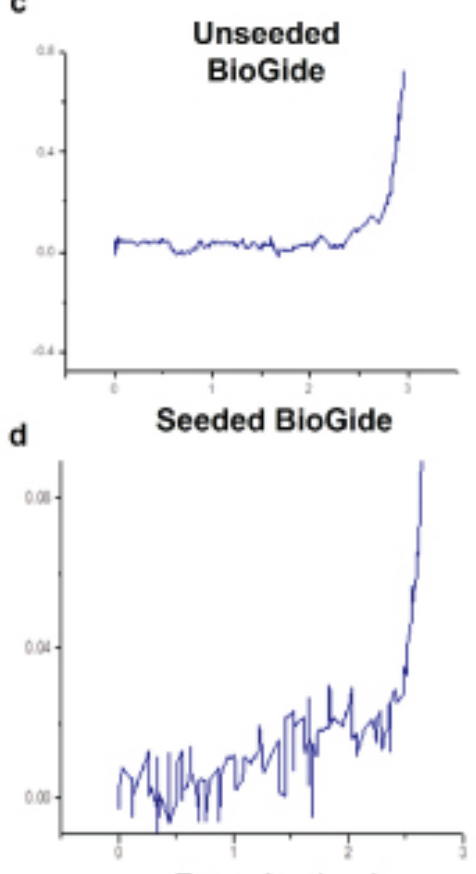

Extension (mm)
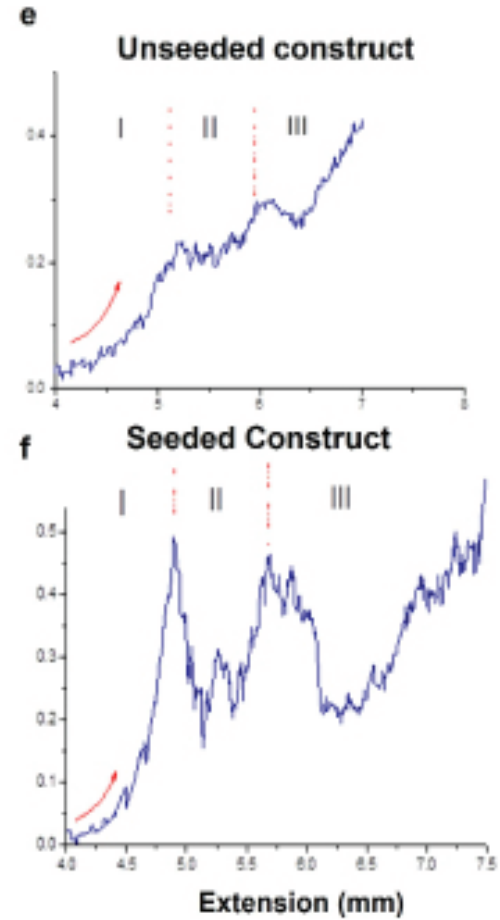

Fig. 5. Line graph showing load-extension curves after compression of 3D structures both seeded and unseeded kept for $2 \mathrm{~W}$ in the same culturing conditions. (a) Un-seeded sol-gel scaffolds. (b) Seeded solgel scaffolds. (c) Un-seeded BioGide ${ }^{\circledast}$. (d) Seeded BioGide ${ }^{\circledast}$. (e) Seeded bilayered construct. (f) Un-seeded bilayered construct.
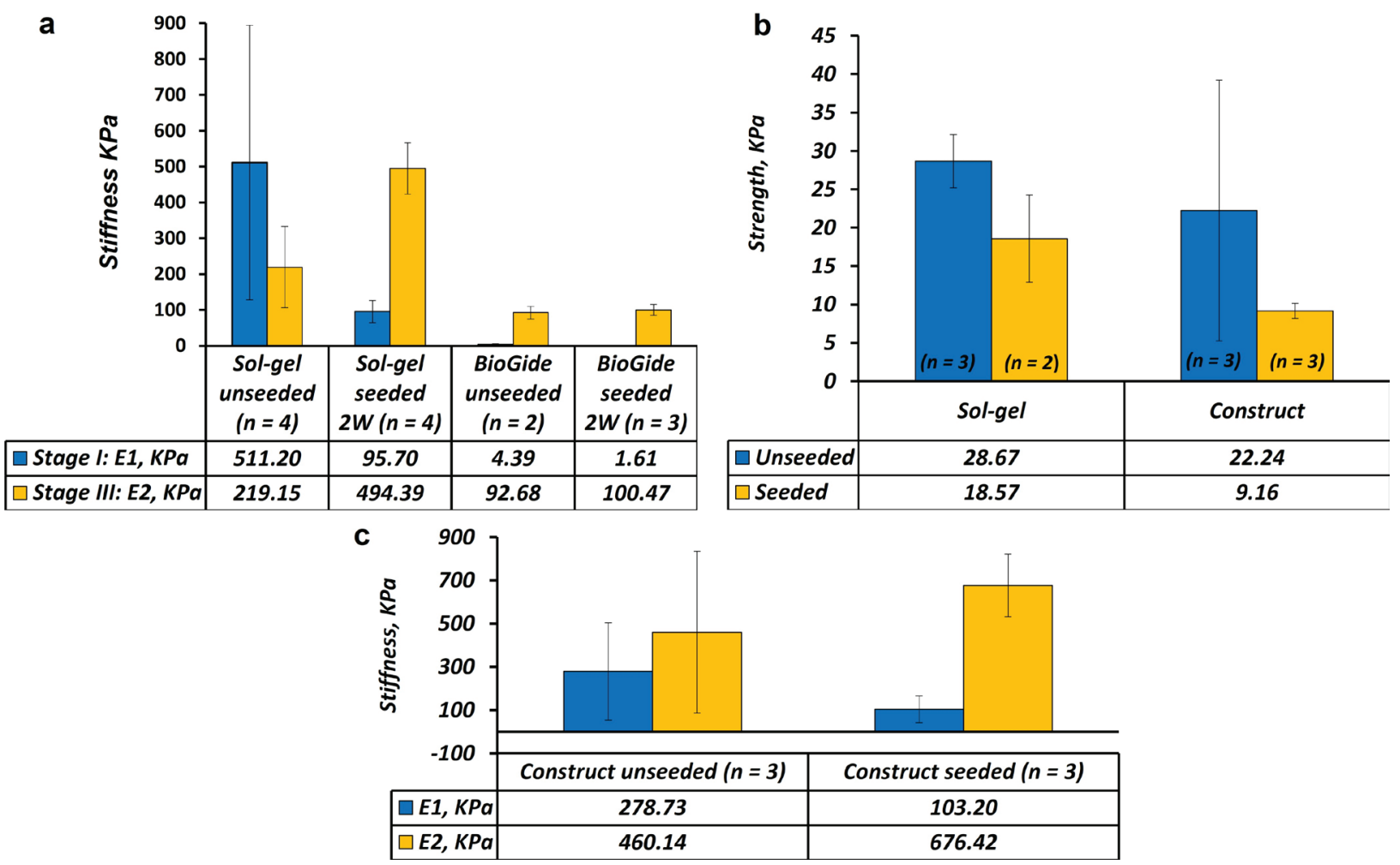

Fig. 6. Relative stiffness change. (a) Graph showing individual scaffolds stiffness (sol-gel scaffold and BioGide ${ }^{\circledR}$ membrane). (b) Graph showing comparison between stiffness of seeded and unseeded constructs. (c) Graph showing peak failure strength during stage I loading. Note: samples not showing peak failure at stage I were excluded. 
a decrease in E1 stiffness of $2 \pm 0.3 \mathrm{KPa}$ and a similar E2 stiffness of $100 \pm 15 \mathrm{KPa}$ (Fig. 5 d).

The bilayer construct showed a non-linear toe region (stage I), with a yield region (stage II) followed by a high stiffness region (stage III), showing similar behaviour to the sol-gel samples (Fig. 5e,f). The stiffness for stage I and II were calculated as E1 and E2 respectively. The unseeded construct at 2 weeks $(n=3)$ showed E1 and E2 values of $279 \pm 224 \mathrm{KPa}$ and $460 \pm 374 \mathrm{KPa}$ respectively (Fig. 5e). In comparison, the seeded construct with HPDLCs at 2 weeks $(n=3)$ showed a decrease in E1 at $103 \pm 62 \mathrm{KPa}$ and a considerable increase in E2 stiffness at $676 \pm 145 \mathrm{KPa}$.

Comparing the unseeded and seeded bilayered constructs after, 2 weeks in culture, there was no statistically significant difference between seeded and unseeded constructs at stage I (Fig. 6a). At stage III, significantly higher stiffness was noticed in the seeded constructs. The peak strength of the sol-gel scaffold and construct samples were calculated as the maximum stress reached during stage I of loading where the foam bears most of the loading before micro-fractures occur in stage II and increasing stress due to foam densification in stage III. The unseeded and seeded sol-gel constructs had higher compressive peak strengths at $29 \pm 3 \mathrm{KPa}$ and $22 \pm 17 \mathrm{KPa}$ compared to the unseeded and seeded construct at $19 \pm 6 \mathrm{KPa}$ and $9 \pm 1 \mathrm{KPa}$ (Fig. 6b).

\section{Relative change of gene expression in HPDLCs cultures}

COL1A1 showed a higher expression in SGC that was separated from the bilayered construct in comparison to individual monolayer cultures in sol-gel scaffolds and Bio-Gide ${ }^{\circledR}$, after 2 weeks of culture. These results were only significant when comparing the SGC and monolayers ( $p \leq 0.05)$. BGC also showed a significantly higher expression of COL1A1 compared to monolayers $(p \leq 0.01)$ and Bio-Gide ${ }^{\circledR}$ cultured individually ( $p \leq 0.001)$ (Fig. 7).

OC showed a significantly higher expression in individual Bio-Gide ${ }^{\circledR}(p \leq 0.001)$ and in monolayer $(p \leq 0.001)$ cultures compared to expression in individual sol-gel after 2 weeks of culture. SGC of the bilayered construct showed significantly higher $O C$ expression compared to the individual sol-gel $(p \leq 0.01)$. The expression of OC in BGC showed no significant difference from the expression in all other groups (Fig. 7).

CEMP1 cultured sol-gel scaffolds showed no significant difference in gene expression between all groups including scaffolds cultured within the bilayered constructs after 2 weeks in culture (Fig. 7).

$O P G$ expression in individually cultured sol-gel, showed significantly higher baseline levels compared to monolayer cultures $(p \leq 0.05)$, individually cultured Bio-Gide ${ }^{\circledR}(p \leq 0.01)$ and SGC $(p \leq 0.05)$. Whereas OPG
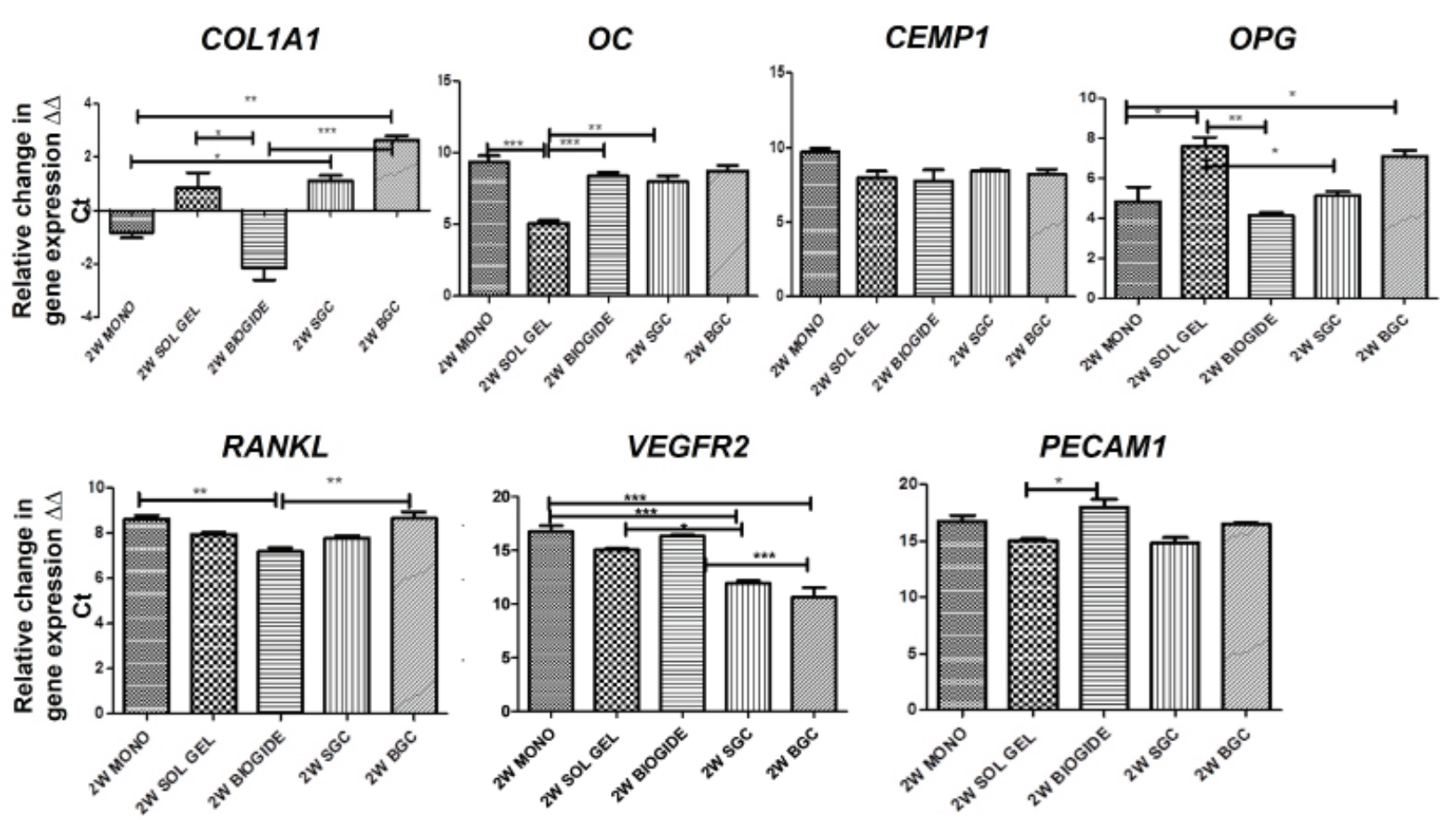

Fig. 7. Relative change in gene expression in HPDLCs cultured for 2 weeks in monolayers, sol-gel scaffold, BioGide $^{\circledR}$ and bilayered construct components after detachment (SGC and BGC). The relative change in expression was normalised to control (zero time point). The data are presented as $\log _{10}$ of the mean $1 \Delta \Delta \mathrm{ct} \pm \mathrm{SD}$. Results analysed using Kurskal Wallis multiple comparison test $\left({ }^{*} p \leq 0.05,{ }^{* *} p \leq 0.01,{ }^{* * *} p \leq 0.001\right)$. 
expression in BGC was only significantly higher than that of monolayer cultures ( $p \leq 0.05)$ (Fig. 7).

RANKL expression was significantly higher in BGC compared to individually cultured BioGide ${ }^{\odot}$ $(p \leq 0.01)$ and was also higher compared to other groups except monolayers; however, this was statistically non-significant. Monolayer cultures also showed a significantly higher RANKL expression, at 2 weeks, compared to individually cultured Bio-Gide ${ }^{\circledR}$ $(p \leq 0.01)$ (Fig. 7).

VEGFR2 expression in the bilayered construct: SGC and BGC, was significantly lower than monolayers and individually cultured constructs after 2 weeks of culture (Fig. 7).

PECAM1 expression at 2 weeks did not show a significant difference between the bilayered construct components and the rest of the groups. However, the PECAM1 expression was significantly higher in individual Bio-Gide ${ }^{\circledR}$ scaffolds compared to individual sol-gel constructs (Fig. 7).

\section{Discussion}

This study involved designing a bilayered construct that allowed culturing cells on 2 different substrate scaffolds representing soft and hard tissues. To be able to establish this bilayered construct, diverse surface textures were required in scaffolds and a cell population that was multipotent and able to create a range of diverse tissues had to be used.

HPDLCs proved to be the best choice, since they are mixed stromal cells that included a subpopulation of stem cells, which maintained stem cell phenotype and characteristics - self-renewal, generating large numbers of progeny that differentiate into multiple mature cell types (Fortier, 2005; Porter and von Fraunhofer, 2005). Furthermore, they are the most appropriate cell source for periodontal tissue engineering (Ivanovski et al., 2006). Moreover, reports show that cells isolated from PDL of healthy and diseased teeth have adult stem cells among the mixed population of PDL cells (Nagatomo et al., 2006; Ramseier et al., 2006). An important feature of HPDLCS is having a subpopulation of cells capable of undergoing differentiation into two types of mineralised tissues, bone and cementum (Inanc et al., 2007). Furthermore, their capability to regenerate the soft tissue PDL component of the periodontium made them a suitable candidate for this study (Inanc et al., 2007).

The normal growth environment of cells within the periodontium is a $3 \mathrm{D}$ environment. Cells grown on flat 2D tissue culture substrates differ considerably in their morphology, cell-cell and cellmatrix interactions, as well as differentiation from those growing in more physiological environments (Yamada and Cukierman, 2007). Furthermore, 3D culture enhances osteogenic differentiation compared to 2D culture (El-Gendy et al., 2013; Inanc et al., 2006). Hence, the selection of suitable scaffolds and their surface topography was of an utmost importance.

The sol-gel derived scaffolds used in this study were a synthetic gelatin-genipin coated bioactive glass (in the system $\mathrm{SiO}_{2}-\mathrm{CaO}-\mathrm{MgO}$ ) structure that fulfills the essential requirements of scaffolds designed for bone regeneration (Hutmacher, 2000; Oreffo et al., 1999; Oreffo and Triffitt, 1999; Rose and Oreffo, 2002). It has shown biocompatibility to PDLCS, as scaffolds should be able to support cell viability and growth without initiating an immune response or any toxic reactions.

The second member of the bilayered construct is the Bio-Gide ${ }^{\circledR}$ membrane. An evident advantage of this membrane is the porous side allowing HPDLCs more surface area to grow within it. In addition, the membrane is made of pure collagen that is the basic structure of PDL (Berkovitz, 2004).

HPDLCs maintained viability and growth after 2 weeks of culture on both types of individual scaffolds as well as within the bilayered construct. This was confirmed by the cell death assay, which showed no significant difference in LDH levels between the different culture conditions. The balance between the construct's porosity and the maintenance of its mechanical properties is a requirement determined by the nature of loading that the construct is supposed to bear in vivo (O'Brien, 2011). In the present study, it was essential to accommodate the balance between the construct porosity, to allow cell growth, and the maintenance of its mechanical properties to withstand loading in vivo (O'Brien, 2011). The compressive stress-strain behaviour of the sol-gel scaffolds was typical of ceramic-based bone-supporting scaffolds showing compressive brittle failure (Chen et al., 2006). The bilayer construct showed compressive behaviour of the BioGide ${ }^{\circledR}$ under low loading, followed by a predominantly brittle loading behaviour as the higher stiffness sol-gel scaffold bore the load. The scaffold material tended to crack initially at stress concentration sites (stage I), causing the apparent strength to drop temporarily, but the specimen as a whole still has the strength to bear more loads causing the stress to rise again and the repetition of this effect leads to the jagged curve in the stage II yield region. The construct material built up more strength at the beginning of (stage III) due to material compaction.

The unseeded sol-gel scaffold's compressive strength range (0.02-0.03 $\mathrm{MPa})$ was an order of magnitude lower than the value for melt-derived bioactive glass scaffolds (0.3-0.4 MPa) (Chen et al., 2006). However, these values were in line with other data published by the group that developed the sol-gel scaffolds, stating compressive strengths of approximately $0.03 \pm 0.005 \mathrm{MPa}$ (Goudouri et al., 2016). The compressive properties of the sol-gel scaffold are relatively low in comparison to other ceramic and polymer bone scaffolds. However, other bone scaffolds are fabricated for use in high load-bearing environments such as bone defects in the lower and upper limbs - requiring high 
initial stiffness values, comparable to cancellous bone (Lichte et al., 2011). In comparison, the sol-gel scaffold is designed for alveolar bone reconstruction, a relatively lower load-bearing environment.

The seeded sol-gel scaffold and construct samples demonstrated smoother stress/strain load behaviour after 2 weeks. This can be attributed to the cell growth within the scaffold filling the micropores and voids, leading to less brittle behaviour - as shown in this study. This change also saw a drop in stiffness. This may be attributed to the stiffness contrast between the high stiffness scaffold struts and low stiffness cellular components. With initial compressive loading, the cellular components of the scaffold yield first - producing a significant toe region. However, an increase in stage III stiffness was observed for the seeded sol-gel scaffolds and construct samples, indicating a decrease in porosity and the load contribution from the cellular components during densification. The other reason why the initial compressive properties (stage I) did not increase after 2 weeks incubation was that the seeded samples were not loaded. However, the aim of this paper was to characterise the construct and subsequent investigations into loading effects will be considered in future studies.

In this study, the excellent pore interconnectivity and porosity of the system, especially within the hard tissue component represented by the sol-gel scaffolds, helped maintain a good tissue perfusion with maintenance of nutrients and cell growth and viability within the bilayered construct, in spite of doubling the thickness. Furthermore, it enhanced attachment and integration between the 2 components of the bilayered construct (Sabree et al., 2015). It is well known that variation in surface topography can change the cues that cells receive and can influence cell differentiation and gene expression (Metavarayuth et al., 2016).

A few studies have investigated the changes in gene expression in multiphasic models of the periodontium. However, many investigated differential gene expression in monolayers (Choi et al., 2011; Lee et al., 2007) or investigated the effect of mechanical loading on the HPDLCs (Berendsen et al., 2009; Shi et al., 2019).

In terms of the length of the culture required, for osteogenic and angiogenic differentiation, earlier studies reported that at least 2 time points (between 2 and 4 weeks of culture) might be recommended to capture the changes in both osteoblastic and angiogenic gene expression profile of stem cells, isolated from dental tissues, in monolayer cultures (Alkharobi et al., 2016; Alkharobi et al., 2018), and on 3D scaffolds (El-Gendy et al., 2015; El-Gendy et al., 2013). This is particularly the case for PDLSCs. Açil et al., (2016) compared osteogenic gene expression under osteogenic induction conditions. Although they mention that they investigated gene expression after 2 and 3 weeks of culture, they only presented data at 2 weeks. They report no changes to RUNX2 expression, but an increased expression of osteopontin and osteonectin at 2 weeks (Açil et al., 2016). The current study was not able, for logistical reasons, to show data at more than one time point or after 2 weeks of culture. It is acknowledged that inability to properly capture the gene expression profile at different timepoints within the model has been a limitation of this study. Gene-expression differences in HPDLCs cultured on sol-gel scaffolds and those cultured on Bio-Gide ${ }^{\circledR}$ were observed.

Angiogenic markers such as VEGFR2 and PECAM1 were both expressed at a higher level in Bio-Gide $^{\circledR}$ compared to sol-gel scaffolds that were cultured individually. Surprisingly, the expression of genes associated with mineralisations, such as OC, had higher expression in individual Bio-Gide ${ }^{\circledR}$ compared to sol-gel scaffolds. This result was in agreement with Alves et al. (2015), who found that 2D collagen type I scaffolds showed higher OC expression by PDLSCs compared to those cultured in 3D collagen type I scaffolds. In the current study, the Bio-Gide ${ }^{\circledR}$ membrane - although having a rough surface topography on one of its sides - was more or less a 2D layer of collagen type I. Conversely, Lee et al. (2013) showed higher dentine and cementum gene expressions on phases representing the hard tissue components of the periodontium in their model.

No significant differences in gene expression between the individual constructs and those detached from the bilayered construct, after 2 weeks of culture, were seen in the current study. This was a reassuring finding as the gene expression remained similar even after increasing the thickness of the construct by assembling the two layers. This was to some extent similar to Zhang et al. (2019), as they did not find a significant change in the expression of osteogenic genes between their untreated controls and their test group of PDLSCs (grown in monolayers) - treated with a combination of A83-01 and FGF-2 after $14 \mathrm{~d}$ of culture. However, they did report a drop in gene expression at $7 \mathrm{~d}$ in the test group. There were some exceptions, such as HPDLCs seeded on the SGC showing a significant increase in $O C$ compared to its individual counterpart - denoting a more advanced osteoblastic differentiation. This had been noted for bioactive glass based scaffolds previously, by the authors' group (El-Gendy et al., 2013). The other couple of exceptions were the significant increase in the expression of RANKL. However, this was not associated with a drop in the OPG, which blocks osteoclastogensis by RANKL. Therefore, this increase in $R A N K L$ expression is not an indication of osteoclastic activity within the constructs. Further investigation of the cell-cell interactions within the construct is required to explain the OPG/RANKL expression observed in this study (Kanzaki et al., 2001). Furthermore, there was a significant drop in VEFGR2 expression in BGC compared to individual Bio-Gide $^{\circledR}$ which was an indication of proper 
oxygenation of the construct, as hypoxia is a major stimulus to increased VEGFR2 expression (Riddle et al., 2009).

A group in Cardiff established what is now known as the gold standard ex vivo model for dentistry and dental regeneration, called the rat mandibular slice model (Smith et al., 2010). This model has shown great success and versatility for investigating the destruction and regeneration of bone and dental tissues under physiological and pathological conditions. This model was also successfully used to investigate the effect of orthodontic forces on bone and PDL (Colombo et al., 2015; El-Bialy et al., 2011; Sloan et al., 2013; Smith et al., 2010). The bilayered model of the current study, however, in addition to its comparability to the mandibular slice model has the added value and versatility of being able to investigate different cell interactions. This is in addition to the seemingly endless options of scaffold materials that can be used in such a model, lending itself not only to dental physiological simulation and regeneration but also expanding its use to other skeletal tissues that require soft-hard tissue interactions.

\section{Conclusion}

A bilayered multiphasic in vitro model was developed for the purpose of periodontium simulation and regeneration. The model was successfully cultured for 2 weeks, maintaining cell viability and attachment as well as gene expression. The model shows versatility that makes it suitable for investigation of cell-cell interactions, cell-materials interaction and the effect or mechanical and orthodontic loading on cell behaviour and tissue regeneration.

\section{Acknowledgements}

The authors wish to acknowledge WELMEC, a Centre of Excellence in Medical Engineering funded by the Welcome Trust and EPSRC, for partially funding this work under grant number WT 088908/z/09/z.

AK would like to acknowledge the Egyptian Ministry of Higher education for funding her PhD.

The Authors would like to acknowledge Geistlich Pharma AG for providing the Bio-Gide ${ }^{\circledR}$ Perio membranes used in this study free of charge.

\section{Conflict of interest statement}

The authors would like to declare no conflict of interest for any of them with the conduct of this study.

\section{References}

Açil Y, Yang F, Gulses A, Ayna M, Wiltfang J, Gierloff M (2016) Isolation, characterization and investigation of differentiation potential of human periodontal ligament cells and dental follicle progenitor cells and their response to BMP-7 in vitro. Odontology 104: 123-135.

Alkharobi H, Alhodhodi A, Hawsawi Y, Alkafaji H, Devine D, El-Gendy R, Beattie J (2016) IGFBP-2 and -3 co-ordinately regulate IGF1 induced matrix mineralisation of differentiating human dental pulp cells. Stem Cell Res 17: 517-522.

Alkharobi HE, Al-Khafaji H, Beattie J, Devine DA, El-Gendy R (2018) Insulin-like growth factor axis expression in dental pulp cells derived from carious teeth. Front Bioeng Biotechnol 6: 36. DOI: 10.3389/ fbioe.2018.00036.

Alves LB, Mariguela VC, Grisi MF, Souza SL, Novaes Junior AB, Taba Junior M, Oliveira PT, Palioto DB (2015) Expression of osteoblastic phenotype in periodontal ligament fibroblasts cultured in threedimensional collagen gel. J Appl Oral Sci 23: 206-214.

Araujo MG, Berglundh T, Lindhe J (1998) GTR treatment of degree III furcation defects with 2 different resorbable barriers. An experimental study in dogs. J Clin Periodontol 25: 253-259.

Bai Y, Bai Y, Matsuzaka K, Hashimoto S, Fukuyama T, Wu L, Miwa T, Liu X, Wang X, Inoue $\mathrm{T}$ (2021) Cementum- and periodontal ligament-like tissue formation by dental follicle cell sheets cocultured with Hertwig's epithelial root sheath cells. Bone 48: 1417-1426.

Berendsen AD, Smit TH, Walboomers XF, Everts V, Jansen JA, Bronckers AL (2009) Three-dimensional loading model for periodontal ligament regeneration in vitro. Tissue Eng Part C Methods 15: 561-570.

Berkovitz BK (2004) Periodontal ligament: structural and clinical correlates. Dent Update 31: 46-54.

Blehert DS, Palmer RJ, Jr., Xavier JB, Almeida JS, Kolenbrander PE (2003) Autoinducer 2 production by Streptococcus gordonii DL1 and the biofilm phenotype of a luxS mutant are influenced by nutritional conditions. J Bacteriol 185: 4851-4860.

Camargo PM, Lagos R, Pirih FQM, Benitez A, Nervina JM, Tetradis S (2005) Prostaglandins E-2 and F-2 alpha enhance differentiation of cementoblastic cells. J Periodontol 76: 303-309.

Camelo M, Nevins ML, Lynch SE, Schenk RK, Simion M, Nevins M (2001) Periodontal regeneration with an autogenous bone-Bio-Oss composite graft and a Bio-Gide membrane. Int J Periodontics Dent 21: 109-119.

Chen Q, Bismark A, Hansen U, Junaid S, Tran M, Harding S, Ali N, Boccanccini A (2008) Characterization of a soft elastomer poly(glycerol sebacate) designed to match the mechanical properties of mycardial tissue. Biomaterials 29: 47-57. 
Chen Q, Thompson I, Boccaccini A (2006) 45 S5 Bioglass ${ }^{\circledR}$ derived glass ceramic scaffolds for bone tissue engineering. Biomaterials 27: 2414-2425.

Cho M-I, Garant PR (2000) Development and general structure of the periodontium. Periodontol 2000 24: 9-27.

Choi MH, Noh WC, Park JW, Lee JM, Suh JY (2011) Gene expression pattern during osteogenic differentiation of human periodontal ligament cells in vitro. J Periodontal Implant Sci 41: 167-175.

Colombo JS, Howard-Jones RA, Young FI, Waddington RJ, Errington RJ, Sloan AJ (2015) A 3D ex vivo mandible slice system for longitudinal culturing of transplanted dental pulp progenitor cells. Cytometry A 87: 921-928.

El-Bialy T, Lam B, Aldaghreer S, Sloan AJ (2011) The effect of low intensity pulsed ultrasound in a 3D ex vivo orthodontic model. J Dent 39: 693-699.

El-Gendy R, Junaid S, Lam SKL, Elson KM, Tipper JL, Hall RM, Ingham E, Kirkham J (2020) Developing a tooth in situ organ culture model for dental and periodontal regeneration research. Front Bioeng Biotechnol 8: 581413. DOI: 10.3389/fbioe.2020.581413.

El-Gendy R, Kirkham J, Newby PJ, Mohanram Y, Boccaccini AR, Yang XB (2015) Investigating the vascularization of tissue-engineered bone constructs using dental pulp cells and 45S5 Bioglass ${ }^{\circledR}$ scaffolds. Tissue Eng Part A 21: 2034-2043.

El-Gendy R, Yang XB, Newby PJ, Boccaccini AR, Kirkham J (2013) Osteogenic differentiation of human dental pulp stromal cells on 45 S5 Bioglass(R) based scaffolds in vitro and in vivo. Tissue Eng Part A 19: 707-715.

El-Sayed B, Davies RPW, El-Zehery RR, Ibrahim FM, Grawish ME, Kirkham J, El-Gendy R (2020) An in vivo Intraoral defect model for assessing the use of P11-4 self-assembling peptide in periodontal regeneration. Front in Bioeng and Biotechnol 8: 559494. DOI: 10.3389/fbioe.2020.559494.

Elisseeff J, Puleo C, Yang F, Sharma B (2005) Advances in skeletal tissue engineering with hydrogels. Ortho Craniofac Res 8: 150-161.

Fortier LA (2005) Stem cells: classifications, controversies, and clinical applications. Vet Surg 34: 415-423.

Gay IC, Chen S, MacDougall M (2007) Isolation and characterization of multipotent human periodontal ligament stem cells. Orthod Craniofac Res 10: 149-160.

Goudouri O-M, Vogel C, Grünewald A, Detsch R, Kontonasaki E, Boccaccini A (2016) Sol-gel processing of novel bioactive $\mathrm{Mg}$-containing silicate scaffolds for alveolar bone regeneration. J Biomat Appl 30: 740-749.

Hutmacher DW (2000) Scaffolds in tissue engineering bone and cartilage. Biomaterials 21: 2529-2543.

Inanc B, Elcin AE, Elcin YM (2006) Osteogenic induction of human periodontal ligament fibroblasts under two-and three-dimensional culture conditions. Tissue Eng 12: 257-266.
Inanc B, Eser E, Elcin A, Demir AK, Baloş K, Parlar A, Elcin YM (2007) Encapsulation and osteoinduction of human periodontal ligament fibroblasts in chitosanhydroxyapatite microspheres. J Biomed Mater Res A 82A: 917-926.

Ivanovski S, Gronthos S, Shi S, Bartold P (2006) Stem cells in the periodontal ligament. Oral Dis 12: 358-363.

Iwata T, Yamato M, Tsuchioka $H$, Takagi R, Mukobata S, Washio K, Okano T, Ishikawa I (2009) Periodontal regeneration with multi-layered periodontal ligament-derived cell sheets in a canine model. Biomaterials 30: 2716-2723.

Jäger M, Sager S, Lensing-Höhn S, Krauspe R (2006) The critical size bony defect in a small animal for bone healing studies (II): implant evolution and surgical technique on a rat's femur. Biomed Eng 50: 137-142.

Jang AT, Lin JD, Seo Y, Etchin S, Merkle A, Fahey K, Ho SP (2014) In situ compressive loading and correlative noninvasive imaging of the boneperiodontal ligament-tooth fibrous joint. J Vis Exp 85: 51147. DOI: 10.3791/51147.

Kanzaki H, Chiba M, Shimizu Y, Mitani H (2001) Dual regulation of osteoclast differentiation by periodontal ligament cells through RANKL stimulation and OPG inhibition. J Dent Res 80: 887891.

Kanzaki H, Chiba M, Takahashi I, Haruyama N, Nishimura M, Mitani H (2004) Local OPG gene transfer to periodontal tissue inhibits orthodontic tooth movement. J Dent Res 83: 920-925.

Koch F, Meyer N, Valdec S, Jung RE, Mathes SH (2020) Development and application of a 3D periodontal in vitro model for the evaluation of fibrillar biomaterials. BMC Oral Health 20: 148. DOI: 10.1186/s12903-020-01124-4.

Lee CH, Hajibandeh J, Suzuki T, Fan A, Shang P, Mao JJ (2013) Three-dimensional printed multiphase scaffolds for regeneration of periodontium complex. Tissue Eng Part A 20: 1342-1351.

Lee Y-H, Nahm D-S, Jung Y-K, Choi J-Y, Kim SG, Cho M, Kim M-H, Chae C-H, Kim S-G (2007) Differential gene expression of periodontal ligament cells after loading of static compressive force. J Periodontol 78: 446-452.

Lichte P, Pape HC, Pufe T, Kobbe P, Fischer H (2011) Scaffolds for bone healing: concepts, materials and evidence. Injury 42: 569-573.

Metavarayuth K, Sitasuwan P, Zhao X, Lin Y, Wang Q (2016) Influence of surface topographical cues on the differentiation of mesenchymal stem cells in vitro. ACS Biomater Sci Eng 2: 142-151.

Nagatomo K, Komaki M, Sekiya I, Sakaguchi Y, Noguchi K, Oda S, Muneta T, Ishikawa I (2006) Stem cell properties of human periodontal ligament cells. J Periodontal Res 41: 303-310.

O'Brien FJ (2011) Biomaterials \& scaffolds for tissue engineering. Mater Today 14: 88-95. 
Oortgiesen DA, Yu N, Bronckers AL, Yang F, Walboomers XF, Jansen JA (2012) A three-dimensional cell culture model to study the mechano-biological behavior in periodontal ligament regeneration. Tissue Eng Part C Methods 18: 81-89.

Oreffo RO, Kusec V, Romberg S, Triffitt JT (1999) Human bone marrow osteoprogenitors express estrogen receptor-alpha and bone morphogenetic proteins 2 and 4 mRNA during osteoblastic differentiation. J Cell Biochem 75: 382-392.

Oreffo RO, Triffitt JT (1999) Future potentials for using osteogenic stem cells and biomaterials in orthopedics. Bone 25: 5S-9S.

Pietruska MD (2001) A comparative study on the use of Bio-Oss ${ }^{\circledR}$ and enamel matrix derivative $\left(\right.$ Emdogain $\left.^{\circledR}\right)$ in the treatment of periodontal bone defects. Eur J Oral Sci 109: 178-181.

Porter JA, von Fraunhofer JA (2005) Success or failure of dental implants? A literature review with treatment considerations. Gen Dent 53: 423-432.

Raju R, Oshima M, Inoue M, Morita T, Huijiao Y, Waskitho A, Baba O, Inoue M, Matsuka Y (2020) Three-dimensional periodontal tissue regeneration using a bone-ligament complex cell sheet. Sci Rep 10: 1656. DOI: 10.1038/s41598-020-58222-0.

Ramseier CA, Abramson ZR, Jin Q, Giannobile WV (2006) Gene therapeutics for periodontal regenerative medicine. Dent Clin North Am 50: 245263.

Riddle RC, Khatri R, Schipani E, Clemens TL (2009) Role of hypoxia-inducible factor- $1 \alpha$ in angiogenic-osteogenic coupling. J Mol Med 87: 583590.

Rose FR, Oreffo RO (2002) Bone tissue engineering: hope vs. hype. Biochem Biophys Res Commun 292: $1-7$.

Sabree I, Gough JE, Derby B (2015) Mechanical properties of porous ceramic scaffolds: influence of internal dimensions. Ceram Int 41: 8425-8432.

Sculean A, Stavropoulos A, Windisch P, Keglevich T, Karring T, Gera I (2004) Healing of human intrabony defects following regenerative periodontal therapy with a bovine-derived xenograft and guided tissue regeneration. Clin Oral Investig 8: 70-74.

Shi J, Baumert U, Folwaczny M, Wichelhaus A (2019) Influence of static forces on the expression of selected parameters of inflammation in periodontal ligament cells and alveolar bone cells in a co-culture in vitro model. Clin Oral Investig 23: 2617-2628.
Sloan AJ, Taylor SY, Smith EL, Roberts JL, Chen L, Wei XQ, Waddington RJ (2013) A novel ex vivo culture model for inflammatory bone destruction. J Dent Res 92: 728-734.

Smith EL, Locke M, Waddington RJ, Sloan AJ (2010) An ex vivo rodent mandible culture model for bone repair. Tissue Eng Part C Methods 16: 1287-1296.

Sumita Y, Honda M, Ohara T, Tsuchiya S, Sgara $\mathrm{H}$ (2006) Performance of collagen sponge as a 3D scaffold for tooth tissue engineering. Biomaterials 27: 3238-3248.

Tsai CC, Huang RN, Sung HW, Liang HC (2000) In vitro evaluation of the genotoxicity of a naturally occurring crosslinking agent (genipin) for biologic tissue fixation. J Biomed Mater Res 52: 58- 65.

Yamada K, Cukierman E (2007) Modeling tissue morphogenesis and cancer in 3D. Cell 130: 601-610.

Yang L, Yang Y, Wang S, Li Y, Zhao Z (2015) In vitro mechanical loading models for periodontal ligament cells: from two-dimensional to three-dimensional models. Arch Oral Biol 60: 413-424.

Yijin R, Jaap CM, Anne MK-J (2006) The rat as a model for orthodontic tooth movement - a critical review and a proposed solution. Eur J Orthod 26: 483-490.

Young C, Terada S, Vacanti J, Honda M, Bartlett J, Yelick P (2002) Tissue engineering of complex tooth structures on biodegradable polymer scaffolds. J Dent Res 81: 695-700.

Yu B-H, Zhou Q, Wang Z-L (2014) Periodontal ligament versus bone marrow mesenchymal stem cells in combination with Bio-Oss scaffolds for ectopic and in situ bone formation: a comparative study in the rat. J Biomater Appl 29: 243-253.

Zhang C, Guo H, Yang C, Chen Q, Huang J, Liu L, Zhang Y, Jin S, Song A, Yang P (2019) The biological behavior optimization of human periodontal ligament stem cells via preconditioning by the combined application of fibroblast growth factor-2 and A83-01 in in vitro culture expansion. J Transl Med 17: 66. DOI: 10.1186/s12967-019-1799-1.

Editor's note: There were no questions from reviewers for this paper, therefore there is no Discussion with Reviewers section. The Guest Editor responsible for this paper was Oriana Trubiani. 